\title{
IAMJ
}

INTERNATIONAL AYURVEDIC MEDICAL JOURNAL

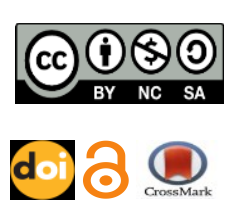

Review Article

ISSN: 2320-5091

Impact Factor: 6.719

\section{A REVIEW OF JIRNA PRATISHYAYA AND ITS AYURVEDIC MANAGEMENT}

\author{
Sunil B. Patil ${ }^{1}$, Rakesh Sharma ${ }^{2}$ \\ ${ }^{1}$ Associate Professor, Department of Kayachikitsa, Smt. K.G. Mittal P. Ayurveda College. Charni Road. \\ Mumbai-02 ${ }^{1}$, Maharashtra, India \\ ${ }^{2}$ Professor, Department of Kayachikitsa, Guru Ravidas Ayurveda University, Punjab, India
}

Corresponding Author: sandeep.sp63@gmail.com

https://doi.org/10.46607/iamj1909022021

(Published online: February 2021)

Open Access

(C) International Ayurvedic Medical Journal, India 2021

Article Received: 25/01/2021 - Peer Reviewed: 02/02/2021 - Accepted for Publication: 06/02/2021

(A) Check for updates

\begin{abstract}
The Present era is full of Chaos, stress and Strain due to lifestyle modification, changes in dietary habits, urbanisation and industrialisation lead to increased pollution and increase resistance to the antibiotics are responsible for prevalence of many diseases. Nose being the prime and nose exposed to the external environment, is more prone to these causative factors and recurrent infection. The most common upsurge of diseases is Jirna Pratishyaya, Repeated attack, improper management or negligence of the acute stage leads the disease to chronic phase. Many treatment modalities are explained in modern system of medicine like corticosteroids, antiallergics, inhalers, antihistamines etc., but none of them are totally effective in curing the disease as well as preventing its recurrence, more over they have their own side effects. In Bruhatrayee, Laghutrayee types, stages are chikitsa is described. Hereby, this is a review compilation of Ayurvedic Classical text in reference to Jirna Pratishyaya and its Chikitsa.
\end{abstract}

Keywords: Jirna Pratishyaya, Nasavarodha, Chronic rhinitis, Ayurveda.

\section{INTRODUCTION}

Due to development of science, the increase in urbanisation is leading to pollution and causing infectious diseases. Pratishyaya is one amongst the commonest Nasagata roga i.e., upper respiratory Tract and is a complex disease involving several symptomatology and diverse pathogenesis. As it is in continuous contact with the external environment and considered as prime site of hyper sensitization. Negligence of acute 
stage or improper management and repeated attacks leads the disease to chronic phase i.e., Jirna Pratishyaya (Chronic Rhinitis).

Pratishyaya is a vata-kaphaj roga and is closely resembling as Rhinitis as described in modern medical science. Characteristic features of Pratishyaya like Nasashrava (running nose), Ghranauparodha (nasal obstruction or congestion), Shirashoola (headache), Shirogauravam (heaviness of head), Jwara (fever), Kasa (cough), Kaphotklesh (phlegm), Swarbheda (hoarseness of voice), Aruchi (anorexia), Klama (tiredness), Indriyanamasamarthyam (altered functions of sense organs) ${ }^{\mathbf{1}}$. If Pratishyaya being left untreated, it develops many conditions like Kasa (cough), Swasa (dyspnoea), Gandhaanjnana (anosmia), Badhirya (deafness) and Rajyakshma (form of disease with multisystem involvement) ${ }^{2}$. In modern science it can be compare with respiratory tract infection i.e., Chronic rhinitis.
More than 120 million Indians suffer from at least one episode of sinusitis each year and, according to the American Academy of Otolaryngology and Head and Neck Surgery, more than 37 million Americans suffer from at least one episode of sinusitis each year. ${ }^{3}$

\section{Aim and Objective:}

1) To study the Literature review of Jirna Pratishyaya

2) To study the Ayurvedic Management of Jirna Pratishyaya

\section{Disease Review:}

\section{Historical Review:}

Pratishyaya is Nasagata (Upper respiratory Tract) disease. It has been described since Samhita kala in Brihattrayee as well as Laghutrayee. It is described as a causative factor of Kasa roga, a Purvarupa of Rajyakshma and as a symptom of Vega vidharan, Kshayaja as well as Vishamasanaja Yakshma. Sushruta Samhita, a separate chapter has been described.

\section{I) Charak Samhita}

\begin{tabular}{|l|l|l|}
\hline $\begin{array}{l}\text { Sthana } \\
\text { Sutra Sthana }\end{array}$ & Chapter & $\begin{array}{l}\text { Description } \\
\text { Vaspa Vegdharana as a Nidan (causative factor) of Pratishyaya }\end{array}$ \\
\hline $\begin{array}{l}\text { Nidana } \\
\text { Sthana }\end{array}$ & 6 (shosha nidan) & $\begin{array}{l}\text { Pratishyaya as a Lakshan (symptom) of Sahasjanya, Dhatukshyaja and Vi- } \\
\text { shamashanaj Sosha. }\end{array}$ \\
\hline $\begin{array}{l}\text { Chikitsa } \\
\text { Sthana }\end{array}$ & $\begin{array}{l}\text { 8(Rajyakshama } \\
\text { Chikitsa Adhyaya) }\end{array}$ & $\begin{array}{l}\text { Pratishyaya is given as a Purvarupa and Lakshana of Yakshma and also described } \\
\text { Samprapti as well as Samanya Chikitsa (General Treatment) of Pinasa (Prat- } \\
\text { ishyaya). }\end{array}$ \\
\hline $\begin{array}{l}\text { Chikitsa } \\
\text { Sthana }\end{array}$ & $\begin{array}{l}\text { 26(Trimarmiya } \\
\text { Chikitsa Adhyaya) }\end{array}$ & $\begin{array}{l}\text { Nidan (Causative factor), Lakshana (Symptoms) as well as Chikitsa (Treatment) of } \\
\text { specific type of Pratishyaya i.e., Vataja, Pittaja, Kaphaja, Tridoshaja Pratishyaya. } \\
\text { Pathya is also given this chapter. } \\
\text { If patients neglect, all types of Pratishyaya changed into Sirna Pratishyaya. }\end{array}$ \\
\hline
\end{tabular}

\section{II) Sushruta Samhita}

\begin{tabular}{|c|c|c|}
\hline $\begin{array}{l}\text { Uttara } \\
\text { Tantra }\end{array}$ & 22(Nasagata Rogavigyana) & Description of five types of Pratishyaya is given \\
\hline $\begin{array}{l}\text { Uttara } \\
\text { Tantra }\end{array}$ & $\begin{array}{l}\text { 24(Pratishyaya } \\
\text { ishedhopkrama) }\end{array}$ & $\begin{array}{l}\text { Hetu, Purvarupa, Lakshana, Chikitsa, Pathyapathya etc., also described } \\
\text { pakwa and apakwa Pratishyaya. }\end{array}$ \\
\hline
\end{tabular}

\section{III) Videha Nimi:}

Has described four stages of Pratishyaya i.e. Purvarupavastha, Rupavastha, Tivravastha and Upshamavastha and their symptoms separately. Acharya describes Pratishyaya as a self-limiting disease. 
IV) Madhava Nidan:

\begin{tabular}{|l|l|l|}
\hline Second Part & 58 (Nasarognidana) & Description of Pratishyaya
\end{tabular}

V) Sharangdhara Samhita:

\begin{tabular}{|l|l|l}
\hline Prathama Khanda & In Nasarog Prakarana of Rogagananadhyaya & Description of Pratishyaya
\end{tabular}

VI) Bhava Prakash Nighantu:

\begin{tabular}{l|l|l} 
Chikitsa Prakaran & 56 (Nasarogadhikar) & Description of Pratishyaya
\end{tabular}

VII) Chakra Dutta:

\begin{tabular}{l|l|l|} 
Chikitsa & 58(Nasaroga & Description of Chikitsa of Pratishyaya and also described Nava and Jeerna
\end{tabular} \begin{tabular}{l|l|l} 
Prakaran & Chikitsa) & Pratishyaya.
\end{tabular}

Etymology: The word "Pratishyaya" is evolved from Dhatu "Shyeng gatau" with Upsarga "prati", means movement of Doshas is continuous in Pratishyaya. The disease in which the tendency of Kaphadi Doshas is move towards Vata or out of nose is called Pratishyaya. And when it is neglected or untreated leads to "Jirna Pratitshyaya".
Nidana: Common Causative factor for Pratishyaya is described in many Samhitas. Acharya Sushruta has described causes of Pratishyaya such as Nariprasanga, Shirashabhitatam, Dhuli, rajah, Shitamatipratapa Mutrapurishasandharanam, etc. (S.S.U.24/3).

Table 1: Nidana of Pratishyaya-

\begin{tabular}{|c|c|c|c|c|}
\hline Aharaj (dietary) & C.S. $^{4}$ & S.S. ${ }^{5}$ & A.S. ${ }^{6}$ & K.S. ${ }^{7}$ \\
\hline Ajeerna & + & & & \\
\hline Mandagni & & & & + \\
\hline Vishamashanam & & & & + \\
\hline $\begin{array}{l}\text { Atiguru, Madhur, Sheeta, Ruksha } \\
\text { sevan }\end{array}$ & & & & + \\
\hline Atijalapana after meals & & & & + \\
\hline Atisheetambupanam & + & & & \\
\hline Viharaj (behavioural) & C.S. & S.S. & A.S. & K.S. \\
\hline Vega sandharana & + & + & + & + \\
\hline Rajahdhumrasevan & + & + & + & \\
\hline Shirasoabhitapam & + & + & & \\
\hline Rituvaishamya & + & & & \\
\hline Atisambhasanam & + & & + & \\
\hline Prajagratiswapnam & + & & + & \\
\hline Atinariprasang & + & + & & \\
\hline Diwasayanam & & + & & \\
\hline Apavitramukhashayanam & & & & + \\
\hline Snana in Ajirna & & & & + \\
\hline Tapa Sevana & & + & & \\
\hline Mansik Hetus & C.S. & S.S. & A.S. & K.S. \\
\hline Atikrodha & + & & & \\
\hline
\end{tabular}


- Stages of Pratishyaya:

According to degree of maturity, Acharya Dalhana described two stages of Pratishyaya viz.

1. Amavastha. 2. Pakwavastha.

1. Amavastha: Symptoms viz. Aruchi, Vaktra virasam, Nasa srava, Rooja, Shirogurutwama, Kshavathu, Jwara etc. (S.S.U.24/12)

2. Pakwavastha: Symptoms viz. Tanutwam ama linganama, Shirolaghuta, Nasalaghuta, Ghanapinkaphatwa etc. (S.S.U.24/12).

- Purvarupa of Pratishyaya: Acharya Sushruta described the symptoms as Shirogurutwama, Kshawathu, Angamarda, and Parihristromta ${ }^{8}$. (S.S.UT.24/5)

According to Acharya Videha, Ghrandhumayanam, Kshavathu,Taludaranam Kanthadhwansa, Mukhasrava, Shirasahpuranam. If above symptoms increase, then purvarupavastha changed into Rupavastha.

Acharya Videha also described the symptoms of Tivravastha of Pratishyaya which are as such Sravadhikya, Nasanaha, Ashrusrava, Jwara, Daurvalya, Shirahashoola.

Acharya Videha also described the symptoms of Upshamavastha of Pratishyaya which are Thick and sticky Nasasrava, opening of Nasasrota, starting of natural respiration, Stopping of Srava.

- Samanya Lakshana: General symptoms of Pratishyaya are only mentioned by Acharya Charaka and Maharishi Kashyapa are as follows:

Acharya Charaka: Shirahshoola, Shirogaurav, Ghranviplava, Jwara, Kasa, Kaphotklesha, Swarabheda, Indriya Asamarthatva9 (C.S.Chi.8/48-49)

Maharishi Kashyapa: Daurgandhta, Parikledita etc ${ }^{\mathbf{1 0}}$. (K.S.Chi.12/4)

- Classification of Pratishyaya: Acharya Sushruta, Vagbhatta, Madhavakara, Bhava Mishra, Sharangadhara have described five types of Pratishyaya i.e., Vataja, Pittaja, Kaphaja, Raktaja, Sannipataja.

Acharya Charaka gives four types of Pratishyaya i.e. Vataja, Pittaja, Kaphaja and Sannipataja, also described Dushta Pratishyaya as advanced stage of Pratishyaya.

Maharishi Kashyapa also described four types of Pratishyaya.

Rasa Ratana Samuchyaya gives six types of Pratishyaya.

Ras Vagbhatta described Malasanchyajanya Pratishyaya.

Table 2: Lakshana of Pratishyaya-

\begin{tabular}{|c|c|c|c|}
\hline Pratishyaya & C.S $\mathbf{S}^{11}$ & S. $S^{12}$ & A.H $\mathbf{H}^{13}$ \\
\hline Vataja & $\begin{array}{l}\text { Ghranatoda, Kshavathu, } \\
\text { Jalabhsrava, Swarabheda. }\end{array}$ & $\begin{array}{l}\text { Anadhyapihita Nasa,Tanu Nasa } \\
\text { Srava, Galtaluosthashosa, } \\
\text { Nistoda Shankha, Swaropghata. }\end{array}$ & $\begin{array}{l}\text { Mukhashosha, Kshavathu, Ghranoprodha, } \\
\text { Shishirkaphasruti, Nistoda Shankha, Shi- } \\
\text { rahshoola, Kitika Eva Sarpanti, Chirapaki. }\end{array}$ \\
\hline Pittaja & $\begin{array}{l}\text { Nasagrapaka, Jwara, Vak- } \\
\text { trashosha, } \\
\text { tasrava. }\end{array}$ & $\begin{array}{l}\text { Krishata, Panduta, Trishna } \\
\text { Nipidita etc }\end{array}$ & $\begin{array}{l}\text { Nasagrapaka, Ushnatamrapittasrava, } \\
\text { Trishna, Bhrama, Ghranapidika. }\end{array}$ \\
\hline Kaphaja & $\begin{array}{l}\text { Kasa, Aruchi, Ghanasrava, } \\
\text { Kandu. }\end{array}$ & $\begin{array}{l}\text { Sheetashuklasrava, Guru- } \\
\text { shiromukhata, Shirogalosthata- } \\
\text { lukandu etc }\end{array}$ & $\begin{array}{lll}\text { Shwasa, Vamana, Gatragaurava, Mukha- } \\
\text { madhurya, } & \text { Aruchi, } & \text { Kandu, } \\
\text { Shuklakaphasruti. } & & \end{array}$ \\
\hline Raktaja & & $\begin{array}{l}\text { Tamrakshi, } \\
\text { gandhyaswasavadan, } \\
\text { Gandhatanaveti, Krimipatana, } \\
\text { Uroghata. }\end{array}$ & $\begin{array}{l}\text { Nasakandu and other symptoms of Raktaja } \\
\text { Pratishyaya is similar to that of Pittaja } \\
\text { Pratishyaya. }\end{array}$ \\
\hline Sannipataja & $\begin{array}{l}\text { Sarvanirupani, Tivra Ruja, } \\
\text { Dukhadayee }\end{array}$ & $\begin{array}{l}\text { Sarvani Rupani, Akasmat Vrid- } \\
\text { dhi and Shanthi }\end{array}$ & Sarvaja Lakshana, Akasmat Vridhishanti. \\
\hline $\begin{array}{l}\text { Dusht Prat- } \\
\text { ishyaya }\end{array}$ & $\begin{array}{l}\text { Acharya Charaka has de- } \\
\text { scribed symptoms of Dusht }\end{array}$ & & $\begin{array}{l}\text { Acharya Vagbhatta have described symp- } \\
\text { toms of Dusht Pratishayaya as Sarvendri- }\end{array}$ \\
\hline
\end{tabular}




$$
\begin{aligned}
& \text { Pratishayaya as Avarodha, } \\
& \text { Abhighata, } \\
& \text { Gandhatnaveti, } \\
& \text { huprakopi. }
\end{aligned}
$$

ya Santapa, Agnimandya, Jwara, Kasa, Urahaparshwashoola, Mukhadaurgandhya, Nasa Kledata and shushkata, Anahyata and Vivriyata.
- Samprapti Ghatak of Pratishyaya

1. Nidan - Kapha vata Prakopak Ahara Vihara

2. Dosha - Kapha Vata Pradhana, Alpa Pitta, Rakta.

3. Dushya-Rasa and Rakta.

4. Agni-Jatharagni, Rasadhatwagni.

5. Srotas - Pranavaha, Rasavaha, Raktavaha.

6. Srotodushti - Sanga, Vimargagamana, Atipravruthi.

7. Adhisthana-Nasa, Shiras.

Pratishyaya Samprapti: According to Acharya Charaka, consumption of etiological factors leading to aggravation of Vatadosha in head and produce Pratishyaya ${ }^{14}$.

Acharya Sushruta describes the manifestation of disease as vitiated Vata and other doshas individually or collectively associated with or without Rakta accumulate in head and produce Pratishyaya ${ }^{15}$.

Acharya Vagbhatta describes as vitiation of VataDosha in nasal cavity leads to pratishyaya ${ }^{\mathbf{1 6}}$

- Chikitsa (Treatment):

Samanya Chikitsa ${ }^{17}$ :

a. Ama Peenasa Chikitsa: Langhana, Deepana, Pachana, Swedan, Ikshu Vikara.

b. Pakwa Peenasa Chikitsa: Shirovirechana, Kavalgraha, Dhoompana, Snepana, Vamana, Virechana, Asthapana, Shaman Aushadha.

c. Acharya Chakradutta: Panchamula Siddha Ghrita, Chitraka Hareetaki, Sarpiguda, Shadanga

\begin{tabular}{|c|c|c|c|}
\hline TYPE & C.S. & S.S. ${ }^{20}$ & A.H. ${ }^{21}$ \\
\hline Vataja & $\begin{array}{l}\text { Ghritapana, Shirovirechana, } \\
\text { Snigdha, Dugdhapana, Mamsarasa, } \\
\text { Dhumrapana, Panisweda, } \\
\text { Upanaha, Sankara Sweda, Niruha } \\
\text { Basti }^{19} \text {. }\end{array}$ & $\begin{array}{l}\text { Ghritapana, Shirovirechana, San- } \\
\text { kara Sweda. }\end{array}$ & $\begin{array}{l}\text { Ghritapana, Shirovirechana, } \\
\text { Sankara Sweda. }\end{array}$ \\
\hline Pittaja & $\begin{array}{l}\text { Ghritapana, Dugdhapana } \\
\text { Nasya, Parishechana } \\
\text { Lepa (Pradeha), Ghreya (Koshna), } \\
\text { Virechana }^{22}\end{array}$ & $\begin{array}{l}\text { Ghritapana, Nasya, Parishechana, } \\
\text { Lepa (Pradeha), Virechana, Kawa- } \\
\text { la Dharana }\end{array}$ & $\begin{array}{l}\text { Ghritapana, Nasya, Par- } \\
\text { ishechana, Lepa (Pradeha) }\end{array}$ \\
\hline Kaphaja & $\begin{array}{l}\text { Ghritapana, Vamana, Nasya, } \\
\text { Langhana, Dhumrapana, Shire } \\
\text { Ghritalepa, Sweda, Parisheka }{ }^{22}\end{array}$ & $\begin{array}{l}\text { Ghritapana } \\
\text { Vamana, Nasya, Dhumravarti, } \\
\text { Antarika, Aushadhisevana }\end{array}$ & $\begin{array}{l}\text { Ghritapana, Vamana, Nasya, } \\
\text { Langhana }\end{array}$ \\
\hline Sannipataja & & $\begin{array}{l}\text { Ghritapana, Dhumrapana, Gutika, } \\
\text { Avaleha, Nasya, Shirovirechana }\end{array}$ & $\begin{array}{l}\text { Ghritapana, Shirovirechana, } \\
\text { Kawala Dharana }\end{array}$ \\
\hline
\end{tabular}
Yusha, Vyoshadi Churna, Nasya by Pathadi Taila and Shadbindu Taila ${ }^{\mathbf{1 8}}$.

\section{Vishesha Chikitsa}

\section{- Upadrava:}

According to Acharya Sushruta: Badhirya (Deafness), Andhata (Blindness), Aghranam (Bodyache), Ghornayanamayam (Severe Eye disease), Kasa (Cough), Agnisada (Loss of Appetite), Shotha (Oedema $)^{\mathbf{2 3}}$. The Sadhya Pranahara Marma (Vital point) Shringataka (Temporal lobe) is the union point of
Srotas (Channels) of Jihwa (tongue), Akshi (Eyes), Nasika (Nose) and Shravanendriya (Ears). Pratishyaya leads to the deterioration of this Marma and causes complications. The Upadrava of Pratishyaya is mostly due to the anatomical relationship and the common blood supply of the organs through which the infections travel. 
- Sadhya-Asadhyata

Acharya Sushruta has described it as Krichchhrasadhya, Vagbhata as Yapya and Madhavakara; Jirna Pratishyaya is either Krichchhrasadhya or Asadhya.

\section{DISCUSSION}

Discussion is the bridge which connects the findings with conclusions. Only a proper discussion can fulfil the purpose of research work.

Acharya Sushruta has described Pratishyaya as a separate chapter in Uttaratantra and it shows its importance Since Ancient times. Pratishyaya is a broad concept which covers all the nasal, Para nasal sinuses, upper and lower respiratory tract infections. Pratishyaya can occur as an independent disease, as a complication of many other diseases or as a symptom of any systemic disorder. Pratishyaya is basically Vata Kaphaja dominant Tridoshaja Vyadi. While analysing all the Nidanas, it is clearly mentioned that the allergens like dust, fumes cause paroxysmal sneezing and rhinorrhoea, while other factors like head injury, seasonal variations, suppressions of natural urges etc. can be potent to initiate the pathological variation of the disease.

Acharya Sushruta describes Nidanas of Pratishyaya as Kalantarajanaka and Sadyojanaka. Sadyojanaka Nidanas can be compared with aggravating factors. Doshas are vitiated and Khavegunya is created due to Kalatarajanaka Nidanas and repeated contact with Sadyojanaka Nidanas cause recurrent attacks of disease.

Stages of Pratishyaya are Amavastha and Pakwavastha, if these stages are being left untreated or mismanagement of these stages leads to severe and more complicated stage i.e., Jirna Pratishyaya.

Acharya Vagbhata has stated that root of every disease is Mandagni, so due to Agnimandya, Sara Dhatu is not formed leading to Alpa Vyadhikshamatva and Agnimandya also leads to vitiation of Doshas due to these factors it becomes very difficult to treat the disease. After analysing all the Nidana in detail, it can be stated that all Nidana are classified under Asatmya Indriyartha Samyoga, Prajnaparadha and Parinama.
These Nidana are the key factor leading to Dosha Dushti which causes Agnimandya and due to $A g$ nimandya_also Dosha Dushti occurs and hence this is a vicious cycle. The symptoms which are found in Pratishyaya can be understood in the light of modern science as below Nasa Srava (Nasal discharge)- It may be watery, purulent, mucopurulent, foul smelling or blood stained according to the intensity of Doshas involved.

In Avegavastha the discharge may be absent. It could be understood that the vitiated Kapha and Pitta remain in the dormant state (Linawastha), as a result the Srava decreases.

In the Vegawastha due to the triggering factors these Doshas are increased causing Srava, Kshavathu (Sneezing) ${ }^{24}$-This is due to reflex action of body to expel out the unnatural, foreign and irritating substances. In chronic stage the sneezing may be less than acute stage. Nasavarodha (Nasal obstruction)-This may be due to anatomical or pathological condition. The common causes of obstructions may be -1 . Oedema of the mucous membrane of the middle turbinate blocking the infundibulum. 2. High deviation of septum causing closure of infundibulum. 3. Hyperplasia of the middle turbinate, which crowds upon the uncinate process and closes the infundibulum. 4. Enlargement of the bulla ethmoidal blocks the infundibulum.

Shira shoola (Headache)- According to Acharya Charak it is one of the common signs of Pratishyaya. It arises due to the congestion and oedema around the sinus ostia. It may be due to Kaphavritta Vata. According to the sinus involvement, the site of pain is different. Swarabheda (Change of voice)-This is due to the absence of nasal resonance. The obstructed nostril and presence of discharge inside the sinus alters the normal resonance mechanism. Here, Dushti of Udana Vayu may be present. Again, the normal Akasha Mahabhuta required for the production of the normal tone, therefore altering the tone of the voice. Ghrana Viplava (Loss of smell)-It is a commonest symptom amongst all other symptoms. This is accounted by the blocking of the olfactory fissure by the tissues in the region of the middle turbinate. Ventila- 
tion of the superior meatus of the nose is there by prevented, hence the loss of the sense of smell. In some chronic cases this may be due to the degeneration of the terminal filaments of the olfactory nerve, although in most cases the sense of smell is regained after the infection has subsided. Here the Dushti of Ghrana Nadi may be present. Again, due to the Kapha Upalepa the olfactory nerve endings are covered and hence the external particles do not come in contact with them, therefore resulting in loss of smell.

Shirogaurava (Heaviness in head)-Retained pus in the sinuses causes the heaviness and fullness in the head. It may be due to the accumulation of vitiated Kapha Dosha which results in the reduction of the normal air spaces in the skull therefore causing the feeling of fullness or heaviness.

Jwara (Fever)-Symptoms like fever, malaise and body ache may be the resulted due to response against infection. It may be due to Ama or circulation of vitiated Dosha in the body. Kasa (Cough)-The postnasal drip can cause lower respiratory tract infections and results into cough. Sometimes it occurs as a symptom and sometimes as a complication. It is also due to Dushti and Pratiloma Gati of Udana Vayu.

Mukha daurgandhya (Halitosis)-The paralysis of cilia and occlusion of ostia will cause the retention of pus in sinuses. So, the long-standing retention will make the pus foul smelling, and this is responsible for the Mukhadaurgandhya. It is mostly seen in maxillary sinusitis as it can also happen due to dental infection. It also may be due to Ama.

\section{CONCLUSION}

Pratishyaya is one of the major diseases in the present era, which is mainly induced due to the inevitable pollution, climate variation and lifestyle developed gradually in society. Pratishyaya is kapha- vata predominating. Factors like Desha, Kala, Vaya of patient has also taken into consideration while treating the disease. Special attention should be given to different stages like Amavastha and Pakwavastha while treating the disease as improper treatment will leads to Ajirna Pratishyaya which is advance stage and more difficult to treat. Chronic phase of disease puts the patient in immuno- compromised state Pathya- Apathya should also be added with the prescribed medicines.

After considering all these factors, it can be concluded that treatment approach should be done to treat and prevent the diseased condition as well as to promote the immunity, physical, mental, spiritual wellbeing of an individual.

\section{REFERENCES}

1. Ed. R.K. Sharma, Bhagawandas, Agnivesha, Charaka Samhita, Commentary Chakrapanidatta, Chowkhamba Sanskrita Series, Varanasi, 1984, Chikitsa Sthana 8/4850 .

2. Sushruta Samhita, Dalhana Commentary Nibandhasangraha, Choukhamba Orientalia, Varanasi, 2009, Uttara tantra 24/16- 17.

3. https://www.ncbi.nlm.nih.gov/pmc/articles/pmc

4. Ed. R.K. Sharma, Bhagawandas, Agnivesha, Charaka Samhita, Commentary Chakrapanidatta Chowkhamba Sanskrita Series, Varanasi, 1984, Chikitsa Sthana 26/104.

5. Sushruta Samhita Dalhana Commentary Nibandhasangraha, Chowkhambha Orientalia Varanasi, 2002, Uttara Tantra 24/3.

6. Ashtanga Hridaya - Sarvanga Sundari Commentary Arunadatta, Choukhambha Krishna Das Academy, Varanasi, 2000, Uttara Sthana 19/1-2.

7. Ed. R.K. Sharma, Bhagawandas, Vriddha Jeevaka. Kashyapa Samhita, Choukhambhya Vishwabharati, Varanasi, 2000, Chikitsa Sthana 12/3.

8. Sushruta. Sushruta Samhita Dalhana CommentaryNibandhasangraha, Chowkhambha Orientalia Varanasi, 2002, Uttara Tantra 24/20.

9. Ed. R.K. Sharma Bhagawandas, Agnivesha. Charaka Samhita, Commentary Chakrapanidatta, Chowkhamba Sanskrita Series, Varanasi, 1984, Chikitsa Sthana 8/4950

10. Ed. P. V. Tiwari, Vriddha Jeevaka. Kashyapa Samhita, Choukhambha Vishwabharati, Varanasi, 2000, Chikitsa Sthana $12 / 4$.

11. Ed. R.K. Sharma, Bhagawandas, Agnivesha. Charaka Samhita, Commentary Chakrapanidatta, Chowkhamba Sanskrita Series, Varanasi, 1984, Chikitsa Sthana 26/105-107. 
12. Sushruta. Sushruta Samhita Dalhana Commentary Nibandhasangraha, Chowkhambha Orientalia Varanasi, 2002, Uttara Tantra 24/6-11.

13. Ashtanga Hridaya - Sarvanga Sundari Commentary Arunadatta, Choukshambha Krishna Das Academy, Varanasi, 2000, Uttara Sthana 19/3-12.

14. Ed Acharya Y.T, Agnivesha. Charaka, Commentary Ayurved Dipika, Choukhamba Surbharti Prakashana, Varanasi, 2009 Chikitsa Sthana 26/105.

15. Sushruta Samhita, Commentary Nibandhasangraha, Choukhamba Orientalia,Varanasi, 2009, Uttara tantra $24 / 4$.

16. Ashtanga Hridaya - Sarvanga Sundari Commentary Arunadatta, Choukhambha Krishna Das Academy, Varanasi, 2000, Uttara Sthana 19/1-2.

17. Sushruta Samhita Dalhana Commentary Nibandhasangraha, Chowkhambha Orientalia Varanasi, 2002, Uttara Tantra 24/19-20.

18. Chakradatta 4th Edn. Chowkhamba Sanskrita Sansthan, Varanasi, 2002, 58/12.

19. Ed. R.K. Sharma, Bhagawandas, Agnivesha. Charaka Samhita, Commentary Chakrapanidatta, Chowkhamba Sanskrita Series, Varanasi, 1984, Chikitsa Sthana 26/107.

20. Sushruta Samhita Dalhana Commentary- Nibandhasangraha, Chowkhambha Orientalia Varanasi, 2002, Uttara Tantra 24/25-41

21. Ashtanga Hridaya - Sarvanga Sundari Commentary Arunadatta, Choukhambha Krishna Das Academy, Varanasi, 2000, Uttara Sthana 20/9- 14.

22. Ed. R.K. Sharma, Bhagawandas, Agnivesha. Charaka Samhita, Commentary Chakrapanidatta, Chowkhamba Sanskrita Series, Varanasi, 1984, Chikitsa Sthana 26/144-150.

23. Sushruta Samhita Dalhana Commentary - Nibandhasangraha, Chowkhambha Orientalia Varanasi, 2002, Uttara Tantra 24/17.

24. Arjuna et.al, WJPR, Pratishyaya the Lifestyle Disorder, 2017, 3(9), 495-400.

\section{Source of Support: Nil \\ Conflict of Interest: None Declared}

How to cite this URL: Sunil B. Patil \& Rakesh Sharma: A Review Of Jirna Pratishyaya And Its Ayurvedic Management. International Ayurvedic Medical Journal \{online\} 2021 \{cited February, 2021\} Available from: http://www.iamj.in/posts/images/upload/439 446.pdf 